\title{
Ionic balance of water and physical-chemical properties of soil from marine shrimp farms of the Jaguaruna interior county, Ceará, Brazil
}

\section{Balanço iônico da água e características físico-químicas do solo de fazendas de camarão marinho do município interiorano de Jaguaruana, Ceará, Brasil}

Francisco Hiago Gadelha Moreira ${ }^{1}$ (D) , Francisco Roberto dos Santos Lima² (D) , Davi de Holanda Cavalcante ${ }^{1}$ (D) , Marcelo Vinícius do Carmo e Sá1

1Programa de Pós-Graduação em Engenharia de Pesca, Universidade Federal do Ceará, Fortaleza, CE Brazil. ${ }^{2}$ Instituto Federal de Educação, IFCE Campus Acaraú, Acaraú, CE Brazil.

${ }^{*}$ Correspondent - marcelo.sa@ufc.br

Section: Recursos Pesqueiros e Engenharia de Pesca

Received

January 30, 2019

Accepted

November 1, 2019

Published

June 16, 2020

www.revistas.ufg.br/vet

visit the website to get the how to cite in the article page.

\section{Abstract}

The present work aimed at describing and characterizing the physical-chemical composition and the $\mathrm{Na}^{+}: \mathrm{K}^{+}$and $\mathrm{Ca}^{+2}: \mathrm{Mg}^{+2}$ ratios of well waters used to fill $L$. vannamei culture ponds, belonging to farms located in Jaguaruana, an interior municipality of the State of Ceará, Brazil. Besides that, the study also sought to describe and characterize the physical-chemical properties of soils from the same shrimp farms. Well water and soil samples were taken in four farms, three located in Jaguaruana (Pasta Branca, Sargento and Poró) and one in the municipality of Aracati, which served as a control. Water samples were analyzed for $\mathrm{pH}$, specific conductance, salinity, total alkalinity, total and calcium hardness, potassium and sodium. Soil samples were analyzed for $\mathrm{pH}$, specific conductance, salinity, potential acidity, phosphorus, organic carbon, total nitrogen, sodium and potassium. The well waters from Aracati, Pasta Branca/Sargento and Poró were classified as euhaline, oligohaline and mesohaline, respectively. The results of $\mathrm{pH}$ indicated that liming was necessary in all four farms. All well waters demanded potassium fertilization to compensate for $\mathrm{K}^{+}$deficiency and to adjust $\mathrm{Na}$ : $\mathrm{K}$ ratio. It has been concluded that, in the productive management of inland shrimp farms, it is important to monitor not only the $\mathrm{Na}: \mathrm{K}$ and $\mathrm{Ca}: \mathrm{Mg}$ ratios of the water, but also the absolute concentrations of each ion.

Keywords: Inland shrimp culture. Sodium. Potassium. Calcium. Magnesium. Low-salinity Waters.

\section{Resumo}

O presente trabalho teve os seguintes objetivos: 1 caracterizar a composição físico-química e as relações $\mathrm{Na}^{+}: \mathrm{K}^{+}$e $\mathrm{Ca}^{+2}: \mathrm{Mg}^{+2}$ da água de poços profundos utilizados no abastecimento de viveiros de criação 
de camarão marinho, Litopenaeus vannamei, pertencentes a fazendas do município interiorano de Jaguaruana, Ceará, Brasil; 2 - caracterizar a composição físico-químico do solo das fazendas de camarão de Jaguaruana. Amostras de água e solo foram coletadas em quatro fazendas, três localizadas em Jaguaruana (Pasta Branca, Sargento e Poró) e uma em Aracati, que serviu como controle experimental. As amostras de água foram analisadas para $\mathrm{pH}$, condutividade elétrica, salinidade, clorinidade, alcalinidade total, dureza total e cálcica, potássio e sódio. As amostras de solo foram analisadas quanto ao $\mathrm{pH}$, condutividade elétrica, salinidade, acidez potencial, fósforo, carbono orgânico, nitrogênio total, sódio e potássio. As águas das fazendas de Aracati, Pasta Branca/Sargento e Poró foram classificadas como eurihalina, oligohalinas e mesohalinas, respectivamente. Os resultados de $\mathrm{pH}$ da água $(6,8 \pm 0,2)$ indicaram a necessidade de calagem em todas as fazendas investigadas. A água de todos os poços demandava a fertilização potássica, tanto para suprir suas concentrações insuficientes, como para ajustar a relação Na: K. Concluiu-se que, no manejo produtivo de fazendas de carcinicultura interior, é importante monitorar não apenas as relações $\mathrm{Na:} \mathrm{K} \mathrm{e} \mathrm{Ca:} \mathrm{Mg} \mathrm{da} \mathrm{água,} \mathrm{mas}$ também as concentrações absolutas de cada íon.

Palavras-chave: Águas subterrâneas, cálcio, carcinicultura interior, magnésio, potássio, sódio.

\section{Introduction}

Nowadays, several countries, such as China, Egypt, Australia, India, Brazil, Ecuador, the United States and Mexico, carry out commercial inland shrimp farming operations. In 2014 , almost $30 \%$ of the 2.7 million tons of shrimps and prawns produced by aquaculture came from farms located far from the coast ${ }^{(1)}$.

In Brazil, the States of Ceará and Rio Grande do Norte are the main producers of cultured shrimp. In Ceará, the major producing municipalities are Aracati, a coastal municipality, and Jaguaruana, in the interior. In Jaguaruana, the shrimp farms produced approximately 5,000 tons of Litopenaeus vannamei in $2015^{(2)}$. Jaguaruana has the greatest number of active shrimp farms in the Ceará, over 200 properties $^{(3)}$. Out of 590 shrimp farms operating in Ceará, more than 250 units are in municipalities far from the coast, such as Alto Santo, Jaguaribara and Limoeiro do Norte.

Inland waters are often deficient and imbalanced in some biologically important ions to marine shrimps. Besides that, the ionic composition of inland waters may vary greatly between different areas and even between different sites of the same farm ${ }^{(4)}$. In general, inland waters have inappropriate concentrations of $\mathrm{K}^{+}, \mathrm{Na}^{+}, \mathrm{Mg}^{+2}$ and $\mathrm{Ca}^{+2}$, having in mind the attainment of good results in the rearing of $L$. vannamei. Although the environmental requirements of marine shrimps for the main ions have not been determined so far, practical experience indicated that ionic concentrations near to 
those observed in seawater, which has been diluted to the same salinity, are suitable for shrimp farming(5). Shrimp farmers could correct ionic deficiencies and imbalances in water by applying fertilizers. Roy et al. ${ }^{(5)}$ and Boyd ${ }^{(6)}$ reported that the application of muriate of potash $(\mathrm{KCl})$ in water at $100 \mathrm{~g} \mathrm{~m}^{-3}$ significantly increased the survival and growth of marine shrimp reared in low salinity water.

Despite the growing economic and social importance of marine shrimp farming in Brazilian inland waters, there is still a significant lack of information about the limnological characteristics of those waters. The present study aimed at describing and characterizing the physical-chemical composition and the $\mathrm{Na}^{+}: \mathrm{K}^{+} ; \mathrm{Ca}^{+2}: \mathrm{Mg}^{+2}$ ratios of drilled well water used to fill the marine shrimp ponds of the inland municipality of Jaguaruana, State of Ceará, Brazil. The water quality of drilled wells from the coastal municipality of Aracati, State of Ceará was used as a reference. Moreover, it was aimed at describing and characterizing the physical-chemical properties of soils in the shrimp farms from Jaguaruana, considering the quality of soil from from Aracati's farms as a reference. Corrective measures were proposed, for each case, looking at the achievement of the best possible growth performance results.

\section{Material and methods}

Water samples were taken in four L. vannamei shrimp farms, three located in the municipality of Jaguaruana, State of Ceará, in the districts of Pasta Branca (PB), Sargento $(\mathrm{SAR})$ and Poró (POR), and one located in the coastal municipality of Aracati, State of Ceará (ARAC). The characteristics of ARAC were used as reference (experimental control). All farms used drilled well water to fill shrimp ponds.

In each farm, three different drilled wells were selected for water sampling. In addition, three below-surface soil samples ( $5 \mathrm{~cm}$ depth) were taken from undisturbed areas of each farm. Soils from Jaguaruana are classified as alluvial. Well water samples were collected twice directly from the source, avoiding contact with the nearby surface soil. Water samples were stored in appropriately labeled 1-L plastic bottles and preserved in a Styrofoam box with ice. Soil samples were collected with a shovel in areas near the wells, where there were no buildings or covering of the natural soil. Random soil sites were drilled to obtain each sample. Soil samples were stored in labeled plastic bags and sent to the laboratory. All water and soil samples were taken in the same day. The physical-chemical analyses started within $48 \mathrm{~h}$ after the collection of the water samples. Soil samples were kept at room temperature until laboratory analysis, three days after collection.

Water samples were taken to the "Laboratório de Ciência e Tecnologia Aquícola" (LCTA), a research unit of the "Departamento de Engenharia de Pesca", "Universidade Federal do Ceará" (UFC), Fortaleza, State of Ceará, to determine the following variables: 1 specific conductance (SC; Instrutherm CD-850 conductivity meter); $\mathrm{pH}$ (MS Tecnopon mPA210 pH-meter); 3 - chlorine (titration with silver nitrate); 4 - total alkalinity (titration with sulfuric acid); 5, 6 and 7 - total, calcium and magnesium hardness (titration with 
EDTA). Water salinity was determined using the following mathematical expression: salinity $\left(\mathrm{g} \mathrm{L}^{-1}\right)=\left[34.5 * \mathrm{SC}\left(\delta \mathrm{S} \mathrm{cm}^{-1}\right)\right] / 50,000$. Those determinations were carried out following the methods of Clesceri et al. ${ }^{(7)}$.

$\mathrm{Na}^{+}$and $\mathrm{K}^{+}$concentrations of the water and soil samples were determined in the "Laboratório de Manejo do Solo" (LMS), "Departamento de Ciências do Solo", UFC, by flame photometry (Micronal B-462 flame photometer).

After breaking the soil cakes with roll and drying by air, samples were analyzed for: 1 - pH (Tecnal pH-meter, using a $\mathrm{KCl} 1 \mathrm{M}$ soil: liquid solution); 2 - specific conductance (Tecnal Tec-4MP conductivity meter, direct reading, saturation extract); potential acidity (calcium acetate solution extraction); 4 - total phosphorus (sulfuric acid extraction); organic carbon (potassium dichromate); 6 - total nitrogen (Kjeldahl). All soil analyses were carried out according with the methodologies described by EMBRAPA(8).

Results of water and soil quality were subjected to descriptive statistics to obtain the mean, standard-deviation and values of minimum and maximum. Results of soil analysis were classified according to salinity in two distinct classes, then subjected to the Student's $t$ test to detect significant differences between the means $(P<0.05)$. The SigmaPlot 12.0 software was used in all statistical analyses.

\section{Results and discussion}

The salinity of water in SAR $\left(0.64 \pm 0.18 \mathrm{~g} \mathrm{~L}^{-1}\right)$ and PB $\left(0.71 \pm 0.25 \mathrm{~g} \mathrm{~L}^{-1}\right)$ were classified as oligohaline; the salinity of water in POR $\left(6.14 \pm 2.14 \mathrm{~g} \mathrm{~L}^{-1}\right)$ as mesohaline. The $\mathrm{pH}$ of the oligohaline (SAR, PB) and mesohaline (POR) wells were acid, below the minimum limit of $\mathrm{pH}$ considered ideal for marine shrimp culture $\left(\mathrm{pH}=7.0-9.0^{(9)}\right.$; Table 1). Except for some wells, the total alkalinity (TA) and total hardness (TH) of the oligohaline wells were suitable for shrimp farming $\left(125.2 \pm 36.7 \mathrm{mg} \mathrm{L}^{-1} ; 204 \pm 61 \mathrm{mg}\right.$ $L^{-1}$, respectively). The TA and TH of the mesohaline wells were also acceptable for $L$. vannamei rearing (185.8 $\pm 7.2 \mathrm{mg} \mathrm{L}^{-1} ; 1956 \pm 499 \mathrm{mg} \mathrm{L}^{-1}$, respectively). All oligohaline and mesohaline wells presented suitable concentrations of $\mathrm{Ca}^{+2}$ for marine shrimp culture. On the other hand, although the mean $\mathrm{Mg}^{+2}$ concentrations were acceptable, some oligohaline and mesohaline wells had improper concentrations of $\mathrm{Mg}^{+2}$ for shrimp rearing $\left(<20 \mathrm{mg} \mathrm{L}^{-1}\right.$, oligohaline water; $<250 \mathrm{mg} \mathrm{L}^{-1}$, mesohaline water). The unsuitability of the well waters for $\mathrm{pH}$ and $\mathrm{Mg}^{+2}$ could be amended by applications of dolomitic agricultural limestone in the rearing tanks. Maia et al..(10) applied $1500 \mathrm{~kg}$ $\mathrm{ha}^{-1}$ dolomitic agricultural limestone in oligohaline marine shrimp ponds to correct the soil $\mathrm{pH}$. However, liming of saline waters with TA over $80 \mathrm{mg} \mathrm{L}^{-1}$ may result in no practical effect because agricultural limestone does not dissolve adequately in such conditions $^{(11)}$. In that case, the application of dolomitic hydrated lime, $\mathrm{Ca}(\mathrm{OH})_{2} \cdot \mathrm{Mg}(\mathrm{OH})_{2}$ in lower dosages would be a better option to the producer.

All oligohaline and mesohaline wells presented very low and inadequate concentrations of $\mathrm{K}^{+}$for rearing marine shrimps in low-salinity waters. Moreover, some oligohaline wells had very low and unsuitable concentrations of $\mathrm{Na}^{+}$and $\mathrm{Cl}^{-}$for the good development 
of L. vannamei. It was suggested the water potability assessment of some SAR and PB wells. If the water is drinkable, it would be more rational to use those aquifers for human consumption instead of animal rearing.

The mesohaline wells presented imbalanced and insufficient concentrations of $\mathrm{Na}^{+}$for rearing marine shrimps in low-salinity waters. Similarly, some mesohaline wells had unsuitable concentrations of $\mathrm{Cl}^{-}$that do not meet the ideal ionic balance for the growth of L. vannamei. Despite the concentrations of $\mathrm{Na}^{+}$and $\mathrm{Cl}^{-}$in the mesohaline wells were outside the ideal range, and considering the respective ionic concentrations of diluted seawater as reference, the strong osmoregulatory capacity of L. vannamei would probably make unnecessary any amendment by the producer. The isosmotic point of L. vannamei is $24.7 \mathrm{~g} \mathrm{~L}^{-1}$. Nevertheless, this species of marine shrimp has an excellent capacity for hyperosmotic regulation ${ }^{(12)}$, being able to adapt itself even to low-salinity waters.

As the water of $\mathrm{SAR}_{1}$ was classified as freshwater, it has been recommended its use for human and animal consumption after a potability assessment (Table 2). The concentrations of $\mathrm{K}^{+}$in SAR varied between 3.6 and $7.2 \mathrm{mg} \mathrm{L}^{-1}$. The well with the highest salinity $\left(\mathrm{SAR}_{3} ; 0.80 \mathrm{~g} \mathrm{~L}^{-1}\right)$ presented the lowest concentration of $\mathrm{K}^{+}$in water $\left(3,6 \mathrm{mg} \mathrm{L}^{-1}\right)$. The $\mathrm{Na}^{+}: \mathrm{K}^{+}$ratios of the SAR's wells varied between 20: $1\left(\mathrm{SAR}_{1}\right)$ and 50: $1\left(\mathrm{SAR}_{3}\right)$. Since the ideal $\mathrm{Na}^{+}: \mathrm{K}^{+}$ratio of water for marine shrimp culture is 28: 1 and the minimum desirable concentration of $\mathrm{K}^{+}$is $50 \mathrm{mg} \mathrm{L}^{-1(5)}$, it was recommended the application of potassium fertilizers in $\mathrm{SAR}_{2}$ and $\mathrm{SAR}_{3}$ (Table 2).

There was no significant correlation between the salinity and concentration of $\mathrm{K}^{+}$of the water wells. Therefore, it would not be possible to estimate the concentration of $\mathrm{K}^{+}$ in the well water by knowing only its salinity. In this case, the shrimp producer should send a water sample for laboratory determination of $\mathrm{K}^{+}$. The increase in $\mathrm{K}^{+}$in water is beneficial to the growth and survival of $L$. vannamei reared in low salinity waters ${ }^{(5,14)}$. Jahan et al. ${ }^{(15)}$ reported greater survival and body weight gain of marine shrimp reared in $\mathrm{K}^{+}$fertilized tanks.

The $\mathrm{Na}^{+}: \mathrm{K}^{+}$ratios in the coastal ARAC wells were imbalanced for the appropriate rearing of marine shrimps in low salinity waters due to the $\mathrm{K}^{+}$deficiency. Therefore, it is suggested that the underground waters, in general, no matter if coastal or interior, require $\mathrm{K}^{+}$applications to achieve the best possible results of shrimp growth performance. Although the most common approach is considering only the ideal $\mathrm{Na+}$ : $\mathrm{K}+$ ratio, it would be wiser to consider not a single value but a $\mathrm{Na}^{+}$: $\mathrm{K}^{+}$ratio range as acceptable for shrimp farming. If a $15 \%$ factor is applied to the $\mathrm{Na}^{+}: \mathrm{K}^{+}$ratio of $28: 1$, the acceptable range of $\mathrm{Na}^{+}: \mathrm{K}^{+}$ratio for marine shrimp culture in low salinity waters would be 24 - 32: 1. This suggestion is supported by Liu et al. ${ }^{(14)}$, who tested different $\mathrm{Na}^{+}: \mathrm{K}^{+}$ ratios in water. These authors concluded that $23-33: 1$ is the range of $\mathrm{Na}^{+}$: $\mathrm{K}^{+}$ratio that would produce the best results of shrimp survival and growth.

In the PB wells with $\mathrm{Na}^{+}: \mathrm{K}^{+}$ratios lower than $24: 1$, the application of a sodium compound would be required to adjust the $\mathrm{Na}^{+}$: $\mathrm{K}^{+}$ratios to the acceptable range (24-32: 1). Ground rock salt would be the most adequate product for applying in that case due to its high availability. Water salinization, however, is only acceptable if the source is unsuitable 
for agriculture, human and animal consumption. Moreover, it would be important to determine if the potassium concentration of water is equal or higher than $50 \mathrm{mg} \mathrm{L}^{-1}$. In Thailand, seawater brines were successfully used to raise the salinity of freshwater shrimp ponds to $2-5 \mathrm{~g} \mathrm{~L}^{-1(5)}$. As the application of rock salt may lead to soil salinization, it is only recommended for areas already improper for other social and economic uses.

Table 1. Values of $\mathrm{pH}$, total alkalinity (TA), total hardness (TH) and concentrations of calcium, magnesium, potassium, sodium and chloride of drilled well water used to fill marine shrimp ponds, Litopenaeus vannamei, located in the districts of Sargento (SAR), Pasta Branca (PB) and Poró (POR), municipality of Jaguaruana, State of Ceará, Brazil. Salinity of the oligohaline wells $(\mathrm{SAR}, \mathrm{PB})=0.68 \pm 0.20 \mathrm{~g} \mathrm{~L}^{-1}\left(0.45-0.99 \mathrm{~g} \mathrm{~L}^{-1}\right)$; salinity of the mesohaline wells $(P O R)=6.14 \pm 2.14 \mathrm{~g} \mathrm{~L}^{-1}\left(3.75-7.87 \mathrm{~g} \mathrm{~L}^{-1}\right)$. Mean \pm S.D. The minimum and maximum values are presented in parentheses $(n=3)$

\begin{tabular}{ccccc}
\hline \multirow{2}{*}{ Variable } & \multicolumn{2}{c}{ Well water } & \multicolumn{2}{c}{ Desirable value } \\
& Oligohaline & Mesohaline & Oligohaline & Mesohaline \\
\hline \multirow{2}{*}{$\mathrm{pH}$} & $6.88 \pm 0.28$ & $6.73 \pm 0.23$ & $7.5-8.5$ & $7.5-8.5$ \\
& $(6.53-7.22)$ & $(6.53-6.99)$ & & \\
$\mathrm{TH}$ & $125.2 \pm 36.7$ & $185.8 \pm 7.2$ & $\geq 100$ & $\geq 100$ \\
& $(82.2-179.2)$ & $(181.2-194.0)$ & & \\
$\mathrm{TH}$ & $204 \pm 61$ & $1956 \pm 499$ & $\geq 200$ & $\geq 1200$ \\
& $(122-272)$ & $(1384-2307)$ & & \\
$\mathrm{Ca}^{2+}$ & $22.2 \pm 5.2$ & $308.4 \pm 102.8$ & $\geq 15$ & $\geq 100$ \\
& $(15.2-30.7)$ & $(190.5-379.0)$ & & \\
$\mathrm{Mg}^{2+}$ & $36.0 \pm 14.2$ & $287.8 \pm 28.9$ & $\geq 20$ & $\geq 250$ \\
& $(16.3-53.8)$ & $(220.5-330.2)$ & & \\
$\mathrm{K}^{+}$ & $6.3 \pm 1.7$ & $5.1 \pm 1.3$ & $\geq 30$ & $\geq 70$ \\
& $(3.6-8.6)$ & $(3.6-6.0)$ & & \\
$\mathrm{Na}^{+}$ & $167.0 \pm 47.6$ & $1232.3 \pm 292.0$ & $\geq 215^{3}$ & $\geq 1900$ \\
& $(125.4-256.0)$ & $(915.0-1489.6)$ & & \\
$\mathrm{Cl}^{-}$ & $279 \pm 108$ & $3950 \pm 832$ & $\geq 385^{3}$ & $\geq 3400$ \\
& $(170-440)$ & $(3000-4550)$ & & \\
\hline
\end{tabular}

\footnotetext{
${ }^{1} \mathrm{TA}$ and $\mathrm{TH}$ in $\mathrm{mg} \mathrm{L}^{-1} \mathrm{CaCO}_{3}$; concentrations of calcium, magnesium, potassium, sodium and chloride in $\mathrm{mg} \mathrm{L}^{-1}$;

${ }^{2}$ The desirable values of $\mathrm{pH}, \mathrm{TA}, \mathrm{TH}$ and ionic concentrations for inland shrimp culture were obtained from Boyd, Thunjai and Boonyaratpalin ${ }^{(6)}$, by considering the average salinities of $\approx 0.7 \mathrm{~g} \mathrm{~L}^{-1}$ (oligohaline wells) and $\approx 6.1 \mathrm{mg} \mathrm{L}^{-1}$ (mesohaline wells);

${ }^{3}$ The minimum salinity of water suitable for $L$. vannamei culture is $0.7 \mathrm{~g} \mathrm{~L}^{-1}$ according to

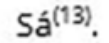


Table 2. Salinity $\left(\mathrm{g} \mathrm{L}^{-1}\right)$, concentrations of sodium, potassium $\left(\mathrm{mg} \mathrm{L}^{-1}\right)$ and $\mathrm{Na}^{+}: \mathrm{K}^{+}$ratio of drilled well water used to fill oligohaline and mesohaline marine shrimp ponds, Litopenaeus vannamei, located in the districts of Sargento (SAR), Pasta Branca (PB) and Poró (POR), municipality of Juaguaruana, State of Ceará, Brazil. Well water from one shrimp farm located in the municipality of Aracati (ARAC) was used as reference

\section{District Well Sal $\mathrm{Na}^{+} \mathrm{K}^{+} \mathrm{Na}^{+} / \mathrm{K}^{+1} \quad$ Recommendation}

\begin{tabular}{|c|c|c|c|c|c|c|}
\hline \multirow{3}{*}{ SAR } & 1 & 0.45 & 125 & 6.2 & 20 & $\begin{array}{l}\text { Possible use for human and } \\
\text { animal consumption. }\end{array}$ \\
\hline & 2 & 0.68 & 158 & 7.2 & 22 & $\begin{array}{l}\text { Apply } \mathrm{KCl} \text { to raise }\left[\mathrm{K}^{+}\right] \text {up to } 30 \\
\mathrm{mg} \mathrm{L}^{-1}\end{array}$ \\
\hline & 3 & 0.80 & 180 & 3.6 & 50 & $\begin{array}{l}\text { Apply } \mathrm{KCl} \text { to raise }\left[\mathrm{K}^{+}\right] \text {up to } 30 \\
\mathrm{mg} \mathrm{L}^{-1}\end{array}$ \\
\hline \multirow{3}{*}{ PB } & 1 & 0.99 & 256 & 6.4 & 40 & $\begin{array}{l}\text { Apply } \mathrm{KCl} \text { to raise }\left[\mathrm{K}^{+}\right] \text {up to } 30 \\
\mathrm{mg} \mathrm{L}^{-1}\end{array}$ \\
\hline & 2 & 0.53 & 145 & 5.6 & 26 & $\begin{array}{l}\text { Possible use for human and } \\
\text { animal consumption. }\end{array}$ \\
\hline & 3 & 0.60 & 136 & 8.6 & 16 & $\begin{array}{l}\text { Apply } \mathrm{KCl} \text { to raise }\left[\mathrm{K}^{+}\right] \text {up to } 30 \\
\mathrm{mg} \mathrm{L}^{-1}\end{array}$ \\
\hline \multirow{3}{*}{ POR } & 1 & 7.87 & 1490 & 6.0 & 248 & $\begin{array}{l}\text { Apply } \mathrm{KCl} \text { to raise }\left[\mathrm{K}^{+}\right] \text {up to } 53 \\
\mathrm{mg} \mathrm{L}^{-1}\end{array}$ \\
\hline & 2 & 6.80 & 1292 & 5.8 & 223 & $\begin{array}{l}\text { Apply } \mathrm{KCl} \text { to raise }\left[\mathrm{K}^{+}\right] \text {up to } 46 \\
\mathrm{mg} \mathrm{L}^{-1}\end{array}$ \\
\hline & 3 & 3.75 & 915 & 3.6 & 254 & $\begin{array}{l}\text { Apply } \mathrm{KCl} \text { to raise }\left[\mathrm{K}^{+}\right] \text {up to } 33 \\
\mathrm{mg} \mathrm{L}^{-1}\end{array}$ \\
\hline \multirow{3}{*}{ ARAC } & 1 & 35.71 & 12563 & 311 & 40 & - \\
\hline & 2 & 30.98 & 9519 & 250 & 38 & - \\
\hline & 3 & 29.66 & 8020 & 205 & 39 & - \\
\hline
\end{tabular}

${ }^{1}$ Ideal $\mathrm{Na}^{+} / \mathrm{K}^{+}$ratio $=28: 1^{(5)}$ 
It was recommended the application of muriate of potash $(\mathrm{KCl})$ in POR to reach the acceptable level of $\mathrm{K}^{+}$, as well to adjust the $\mathrm{Na}^{+}$: $\mathrm{K}^{+}$ratio. The marine ecosystem is naturally rich in potassium. Potassium is the sixth most concentrated ion in seawater with approximately $400 \mathrm{mg} \mathrm{L}^{-1(16)}$. The contact and interaction between the coastal soil and seawater promote the enrichment of the soil with potassium. This is the most plausible explanation for the higher concentrations of $\mathrm{K}^{+}$in the coastal wells (ARAC) in relation to the wells SAR and PB. Part of the $\mathrm{K}^{+}$ions remain in solution; part is adsorbed to the soil. The strong adsorption of $\mathrm{K}+$ by the sediments makes necessary the frequent application of potassium fertilizers in water, aiming to keep the $\mathrm{K}^{+}$concentrations always over $50 \mathrm{mg} \mathrm{L}^{-1}$. In the USA, low salinity shrimp ponds have received potassium fertilization several times per year, even in the units where $\mathrm{K}^{+}$has been applied for over 10 years ${ }^{(17)}$. Roy et al. ${ }^{(5)}$ reported that the soil adsorbs $\mathrm{K}^{+}$ through different ionic exchange processes and part of the $\mathrm{K}^{+}$adsorbed to the soil remains unavailable to the shrimp.

Since the minimum concentration of $\mathrm{Mg}^{+2}$ in low-salinity waters for marine shrimp rearing is $100 \mathrm{mg} \mathrm{L}^{-1(5)}$, it was recommended the application of $\mathrm{MgSO}_{4}$ in the waters from $\mathrm{SAR}_{2}$ and $\mathrm{SAR}_{3}$ (Table 3). Nehru et al. (18) observed the best $L$. vannamei growth performance when the concentrations of $\mathrm{Mg}^{+2}$ in water were increased from 40 up to $80 \mathrm{mg} \mathrm{L}^{-1}$. Although the application of magnesium fertilizer in water may bring positive effects on the growth of $L$. vannamei, this procedure usually has no economic feasibility because the extra weight gain of shrimp does not exceed the additional costs involved with the purchase of the products.

It is recommended the application of $\mathrm{MgSO}_{4}$ in waters from $\mathrm{PB}_{1}$ and $\mathrm{PB}_{3}$. Unlike $\mathrm{SAR}$, the PB's waters had higher $\mathrm{Ca}$ : Mg ratios, out of the acceptable range for rearing marine shrimps in low-salinity waters. This justifies the application of magnesium fertilizer to PB's waters. It is not known the Ca: Mg ratio beyond which there would be economic feasibility for applying magnesium fertilizers in oligohaline shrimp tanks. This is a research topic that deserves a further investigation. In SAR and PB, the concentrations of $\mathrm{Ca}^{+2}$ in water were from moderate to low, for the proper rearing of marine shrimps. Hence, it is suggested the application of dolomitic agricultural limestone or hydrated lime to simultaneously increase the calcium and magnesium hardness of water.

In two of the mesohaline wells from POR, there were high concentrations of $\mathrm{Ca}^{+2}$ and $\mathrm{Mg}^{+2}$. In those waters, however, the $\mathrm{Ca}: \mathrm{Mg}$ ratios were well above the upper acceptable limit (0.340). In other words, there were much calcium for the actual level of magnesium in $\mathrm{POR}_{1}$ and $\mathrm{POR}_{2}$. Yet, as the magnesium concentrations were already high in those wells, over $300 \mathrm{mg} \mathrm{L}^{-1}$, there would be no rationale to apply magnesium fertilizers in that case. This demonstrates the importance to simultaneously consider the Ca: $\mathrm{Mg}$ ratio as well as the absolute concentrations of dissolved $\mathrm{Ca}^{+2}$ and $\mathrm{Mg}^{+2}$ in water.

Potassium fertilization in low-salinity marine shrimp ponds is more important than magnesium fertilization. Fertilization with magnesium is justifiable only in extreme 
cases such as when the Mg levels in water were below $20 \mathrm{mg} \mathrm{L}^{-1}$. Davis et al. ${ }^{(19)}$ reported that the potassium and magnesium applications in water increase the survival of shrimp, in which the potassium fertilization had more clear effects on the growth of L. vannamei reared in low-salinity waters.

Table 3. Salinity $\left(\mathrm{g} \mathrm{L}^{-1}\right)$, concentrations of calcium, magnesium $\left(\mathrm{mg} \mathrm{L}^{-1}\right)$ and $\mathrm{Ca}^{+2}: \mathrm{Mg}^{+2}$ ratios of drilled well water used to fill oligohaline and mesohaline marine shrimp ponds, Litopenaeus vannamei, located in the districts of Sargento (SAR), Pasta Branca (PB) and Poró (POR), municipality of Juaguaruana, State of Ceará, Brazil. Well water from one shrimp farm located in the municipality of Aracati (ARAC) was used as reference.

\begin{tabular}{|c|c|c|c|c|c|c|}
\hline District & Well & Sal & $\mathrm{Ca}^{2+}$ & $\mathrm{Mg}^{2+}$ & $\mathrm{Ca}^{2+} / \mathrm{Mg}^{2+1}$ & Recommedation ${ }^{2}$ \\
\hline \multirow{3}{*}{ SAR } & 1 & 0.45 & 22.2 & 16.3 & 1.362 & $\begin{array}{l}\text { Possible use for human and } \\
\text { animal consumption. }\end{array}$ \\
\hline & 2 & 0.68 & 15.2 & 42.7 & 0.355 & $\begin{array}{l}\text { Apply } \mathrm{MgSO}_{4} \text { to raise }\left[\mathrm{Mg}^{2+}\right] \\
\text { up to } 100 \mathrm{mg} \mathrm{L}^{-1}\end{array}$ \\
\hline & 3 & 0.80 & 20.2 & 53.8 & 0.376 & $\begin{array}{l}\text { Apply } \mathrm{MgSO}_{4} \text { to raise }\left[\mathrm{Mg}^{2+}\right] \\
\text { up to } 100 \mathrm{mg} \mathrm{L}^{-1}\end{array}$ \\
\hline \multirow{3}{*}{ PB } & 1 & 0.99 & 30.7 & 45.5 & 0.675 & $\begin{array}{l}\text { Apply } \mathrm{MgSO}_{4} \text { to raise }\left[\mathrm{Mg}^{2+}\right] \\
\text { up to } 103.7 \mathrm{mg} \mathrm{L}^{-1}\end{array}$ \\
\hline & 2 & 0.53 & 20.2 & 22.9 & 0.883 & $\begin{array}{l}\text { Possible use for human and } \\
\text { animal consumption. }\end{array}$ \\
\hline & 3 & 0.60 & 24.9 & 34.9 & 0.713 & $\begin{array}{l}\text { Apply } \mathrm{MgSO}_{4} \text { to raise }\left[\mathrm{Mg}^{2+}\right] \\
\text { up to } 100 \mathrm{mg} \mathrm{L}^{-1}\end{array}$ \\
\hline \multirow{3}{*}{ POR } & 1 & 7.87 & 379.0 & 330.2 & 1.148 & - \\
\hline & 2 & 6.80 & 355.7 & 312.5 & 1.138 & - \\
\hline & 3 & 3.75 & 190.5 & 220.5 & 0.864 & $\begin{array}{l}\text { Apply } \mathrm{MgSO}_{4} \text { to raise }\left[\mathrm{Mg}^{2+}\right] \\
\text { up to } 250 \mathrm{mg} \mathrm{L}^{-1}\end{array}$ \\
\hline \multirow{3}{*}{ ARAC } & 1 & 35.71 & 229.3 & 1632.2 & 0.141 & $\begin{array}{l}\text { Apply } \mathrm{CaSO}_{4} \text { to raise }\left[\mathrm{Ca}^{2+}\right] \\
\text { up to } 483 \mathrm{mg} \mathrm{L}^{-1}\end{array}$ \\
\hline & 2 & 30.98 & 124.4 & 1721.8 & 0.072 & $\begin{array}{l}\text { Apply } \mathrm{CaSO}_{4} \text { to raise }\left[\mathrm{Ca}^{2+}\right] \\
\text { up to } 510 \mathrm{mg} \mathrm{L}^{-1}\end{array}$ \\
\hline & 3 & 29.66 & 73.9 & 1601.5 & 0.046 & $\begin{array}{l}\text { Apply } \mathrm{CaSO}_{4} \text { to raise }\left[\mathrm{Ca}^{2+}\right] \\
\text { up to } 474 \mathrm{mg} \mathrm{L}^{-1}\end{array}$ \\
\hline
\end{tabular}


Soil salinity of PB and POR presented a SC $<4 \mathrm{mS} \mathrm{cm}^{-1}$ and they were classified as normal or low; the soils of SAR and ARAC had a SC $>4 \mathrm{mS} \mathrm{cm}^{-1}$, being classified as saline or highly saline (20). The $\mathrm{pH}$ was not significantly different between the high-salinity (SAR, ARAC) and low-salinity soils (PB, POR; Table 4). The mean pH of soil was $6.29 \pm 1.26$. The SC and $\mathrm{Na}^{+}$concentrations of the high-salinity soils were much higher than the respective values observed in the low-salinity soils $(P<0.05)$. The SC of the high-salinity soils were almost eight times higher than those for the low-salinity soils. The $\mathrm{Na}^{+}$in the high-salinity soils was more than five times higher than in the low-salinity soils. Marine shrimp farms should be installed in already saline areas, such as those hypersaline and unproductive lands located near the coast ("apicuns" and "salgados"). Soil and water table salinization is one of the possible environmental impacts of the marine shrimp culture, which must be avoided with appropriate measures. It is usual the use of water withdrawn from the estuary, salty lagoons or even the ocean for filling the shrimp ponds. When the evaporation of water takes place, salts accumulate over the productive cycle. Hence, the shrimp pond effluents became saline and could deteriorate the nearby natural ecosystems $^{(21)}$. Pond lining with impermeable membranes and the water reuse are important measures to prevent the salinization of the receiving water bodies. The application of fertilizers may also increase the salinity of the pond. McNevin et al. (22) reported that the salinity of water increased from $2.6 \mathrm{~g} \mathrm{~L}^{-1}$ to almost $4.0 \mathrm{~g} \mathrm{~L}^{-1}$ after the applications of muriate of potash and potassium sulfate. Therefore, it would be important to examine the effects of the ionic supplementation of water on the salinity of soils in marine shrimp farm.

No significant differences were detected for the concentrations of $\mathrm{K}^{+}$between the high-and low-salinity soils. On average, the $\mathrm{K}^{+}$level in soil was $151.5 \pm 72.1 \mathrm{mg} \mathrm{kg}^{-1}$. The organic carbon (OC) and nitrogen (N) concentrations were higher in the lowsalinity soils than in the high-salinity ones $(P<0.05)$. OC concentrations were almost $50 \%$ higher in the low-salinity soils and $N$ concentrations were more than $30 \%$ higher. Soil salinization reduces the benthic activity, negatively affecting macro- and microorganisms. Consequently, it causes a decline in benthic biodiversity. This is a possible explanation for the lower fertility of soils degraded by salinization.

Unlike $N$, the concentrations of $P$ were higher in high-salinity soils $(P<0.05)$. The levels were almost three times higher in high-salinity soils than in low-salinity ones. The potential acidity of soil did not significantly differ between high- and low-salinity soils $(P<0.05)$. On average, the potential acidity of soil was $1.75 \pm 0.25 \mathrm{cmolc} \mathrm{dm}^{-3}$. Soils with higher salinity have a greater ability to adsorb phosphates ${ }^{(16)}$. Therefore, phosphorus fertilization of shrimp ponds with soil of higher salinity would be more expensive because greater losses would be expected to the sediments. 
Table 4. Values of $\mathrm{pH}$, specific conductance (SC), potential acidity (P Ac) and concentrations of sodium, potassium, organic carbon (OC), nitrogen and phosphorus of soil samples taken in marine shrimp farms, Litopenaeus vannamei, located in the districts of Sargento (SAR), Pasta Branca (PB) and Poró (POR), municipality of Juaguaruana, and in the coastal municipality of Aracati, State of Ceará, Brazil. Mean \pm S.D $(n=6)$. The minimum and maximum values are presented in parentheses.

\begin{tabular}{cccc}
\hline \multirow{2}{*}{ Variable $^{2}$} & \multicolumn{2}{c}{ Soil $^{1}$} & \multirow{2}{*}{ P-value $^{3}$} \\
\cline { 2 - 3 } & Low salinity & High salinity & \\
\hline \multirow{2}{*}{$\mathrm{pH}$} & $6.46 \pm 0.68$ & $6.69 \pm 1.06$ & \multirow{2}{*}{$\mathrm{ns}^{4}$} \\
& $(5.24-7.11)$ & $(5.18-7.62)$ & \\
$\mathrm{SC}$ & $1.57 \pm 0.79$ & $12.16 \pm 7.15$ & 0.005 \\
& $(0.61-2.52)$ & $(4.91-19.15)$ & \\
$\mathrm{Na}^{+}$ & $463 \pm 336$ & $2489 \pm 1476$ & \multirow{2}{*}{0.008} \\
& $(156-910)$ & $(900-4074)$ & \\
$\mathrm{K}^{+}$ & $155 \pm 41$ & $130 \pm 45$ & $\mathrm{~ns}$ \\
& $(118-228)$ & $(68-192)$ & \\
$\mathrm{OC}$ & $91.2 \pm 7.6$ & $61.7 \pm 17.0$ & 0.003 \\
& $(79.4-100.2)$ & $(42.8-80.6)$ & \\
$\mathrm{N}$ & $570.9 \pm 59.0$ & $427.6 \pm 139.6$ & 0.043 \\
& $(501.7-653.3)$ & $(280.0-595.0)$ & \\
$\mathrm{P}$ & $25.4 \pm 7.4$ & $72.0 \pm 44.0$ & \multirow{2}{*}{0.028} \\
& $(15.9-34.1)$ & $(23.0-126.0)$ & \\
$\mathrm{PAC}$ & $1.93 \pm 1.11$ & $1.57 \pm 1.96$ & $\mathrm{~ns}$ \\
\hline
\end{tabular}

\footnotetext{
${ }^{1}$ Soil samples from PB and POR districts had SC $<4 \mathrm{mS} \mathrm{cm}^{-1}$, and were classified as lowsalinity soil samples ${ }^{(20)}$. Soil samples from the districts of SAR and ARAC had SC $>4 \mathrm{mS} \mathrm{cm}^{-1}$ and were classified as high-salinity soil samples:

${ }^{2}$ SC: specific conductance $\left(\mathrm{mS} \mathrm{cm}^{-1}\right), \mathrm{Na}^{+}$and $\mathrm{K}^{+}\left(\mathrm{mg} \mathrm{kg}^{-1}\right)$, OC: organic carbon $\left(\mathrm{g} \mathrm{kg}^{-1}\right), \mathrm{N}$ and P

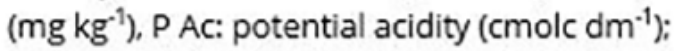

${ }^{3}$ The results for each variable were pooled (PB, POR $\times$ SAR, ARAC) and compared to each other by the Student's t test at the $5 \%$ significance level;

${ }^{4}$ Non-significant (P-value $\left.>0.05\right)$.
} 


\section{Conclusions}

Salinity of the drilled well water in marine shrimp farms of Sargento, Pasta Branca and Poró, municipality of Jaguaruana, State of Ceará, varies greatly, ranging from freshwater $\left(0.45 \mathrm{~g} \mathrm{~L}^{-1}\right)$ to mesohaline water $\left(7.87 \mathrm{~g} \mathrm{~L}^{-1}\right)$.

Values of $\mathrm{pH}$ of water from the drilled wells in the marine shrimp farms of Sargento, Pasta Branca and Poró are slightly acidic ( $\mathrm{pH}=6.8 \pm 0.2$ ). For this reason, it is recommended the liming of the shrimp ponds filled with the water from those wells, before stocking the animals.

The concentrations of $\mathrm{K}^{+}$are low $\left(3.6-8.6 \mathrm{mg} \mathrm{L}^{-1}\right)$ in the drilled well water from the marine shrimp farms of Sargento, Pasta Branca and Poró. Those $\mathrm{K}^{+}$concentrations are far below the minimum level recommended for shrimp farming $\left(50 \mathrm{mg} \mathrm{L}^{-1}\right)$. Therefore, it is recommended the application of potassium fertilizer in the water of shrimp ponds to achieve the best growth performance possible.

In inland shrimp culture, it is important to check out not only the $\mathrm{Na}^{+} / \mathrm{K}^{+}$and $\mathrm{Ca}^{+2} / \mathrm{Mg}^{+2}$ ratios in water, but also the absolute concentrations of those ions.

\section{References}

1. Leon-Canedo JA, Alarcon-Silvas SG, Fierro-Sanudo JF, Mariscal-Lagarda MM, Diaz-Valdes T, PaezOsuna F. Assessment of environmental loads of $\mathrm{Cu}$ and $\mathrm{Zn}$ from intensive inland shrimp aquaculture. Environmental Monitoring and Assessment. 2017 Feb;189(2):69. Disponível em: https://link.springer. com/article/10.1007/s10661-017-5783-z.

2. Pesquisa Pecuária Municipal: Produção da aquicultura, por tipo de produto [Internet]. Rio de Janeiro: Instituto Brasileiro de Geografia e Estatística; [citado 2018 Mar 23]. Disponível em: https://sidra.ibge.gov. br/Tabela/3940.

3. Associação Brasileira de Criadores de Camarão. Censo da carcinicultura do litoral sul do Estado do Ceará e zonas interioranas adjacentes. Natal: ABCC; 2017 Nov. 54 p.

4. Valenzuela-Madrigal IE, Valenzuela-Quinonez W, Esparza-Leal HM, Rodriguez-Quiroz G, AragonNoriega EA. Effects of ionic composition on growth and survival of white shrimp Litopenaeus vannamei culture at low-salinity well water. Revista de Biología Marina y Oceanografía. 2017 Apr;52(1):103-112. Disponível em: https://www.redalyc.org/pdf/479/47950143008.pdf.

5. Roy LA, Davis DA, Saoud IP, Boyd CA, Pine HJ, Boyd CE. Shrimp culture in inland low salinity waters. Reviews in Aquaculture. 2010 Nov;2(4):191-208. Disponível em: https://onlinelibrary.wiley.com/doi/ full/10.1111/j.1753-5131.2010.01036.x.

6. Boyd CE, Thunjai T, Boonyaratpalin M. Dissolved salts in waters for inland, low-salinity shrimp culture. Global Aquaculture Advocate. 2002 Jan;5(3):40-45. 
Ionic balance of water and physical-chemical properties of soil from marine shrimp farms...

Moreira F.H.G. et al.

7. Clesceri LS, Greenberg AE, Eaton AD. Standard methods for the examination of water and wastewater. 20.ed. Washington, DC: American Public Health Association; 1998.

8. EMPRESA BRASILEIRA DE PESQUISA AGROPECUÁRIA. Manual de Métodos de Análise de Solo. 2. ed. Rio de Janeiro: Embrapa Solos; 2011.230 p.

9. Furtado PS, Poersh LH, Wasielesky W Jr. Effect of calcium hydroxide, carbonate and sodium bicarbonate on water quality and zootechnical performance of shrimp Litopenaeus vannamei reared in bio-flocs technology (BFT) systems. Aquaculture. 2011 Nov;321(1-2):130-135. Disponível em: https://doi. org/10.1016/j.aquaculture.2011.08.034.

10. Paiva Maia E, Alves Modesto G, Otavio Brito L, Olivera Galvez A, Vasconcelos Gesteira TC. Intensive culture system of Litopenaeus vannamei in commercial ponds with zero water exchange and addition of molasses and probiotics. Revista de Biología Marina y Oceanografía. 2016 Apr;51(1):61-67. Disponível em: https://www.redalyc.org/pdf/479/47945599006.pdf.

11. Sá MVC, Boyd CE. Dissolution rate of calcium carbonate and calcium hydroxide in saline waters and its relevance for aquaculture. Aquaculture. 2017 Feb;469(1):102-105. Disponível em: https://doi. org/10.1016/j.aquaculture.2016.11.033.

12. Castille FL, Lawrence AL. The effect of salinity on the osmotic, sodium and chloride concentrations in the hemolymph of euryhaline shrimp of the genus Penaeus. Comparative Biochemistry and Physiology Part A: Physiology. 1981 Jan;68(1):75-80. Disponível em: https://doi.org/10.1016/0300-9629(81)90320$\underline{0}$.

13. Sá, MVC. Limnocultura: limnologia para aquicultura. Fortaleza: Edições UFC, 2012. 218 p.

14. Liu H, Tan B, Yang J, Lin Y, Chi S, Dong X, Yang Q. Effect of various Na/K ratios in low-salinity well water on growth performance and physiological response of Pacific white shrimp Litopenaeus vannamei. Chinese Journal of Oceanology and Limnology. 2014 Jul;32(5):991-999. Disponível em: https://link.springer.com/ article/10.1007/s00343-014-3345-6.

15. Jahan I, Reddy AK, Sudhagar SA, Harikrishna V, Singh S, Varghese T, Srivastava P.P. The Effect of Fortification of Potassium and Magnesium in the Diet and Culture Water on Growth, Survival and Osmoregulation of Pacific White Shrimp, Litopenaeus vannamei Reared in Inland Ground Saline Water. Turkish Journal of Fisheries and Aquatic Sciences. 2018 Jan;18(10):1235-1243. Disponível em: http://www. trjfas.org/abstract.php?lang=en\&id=1267.

16. Boyd CA, Boyd CE, Rouse DB. Potassium Adsorption by Bottom Soils in Ponds for Inland Culture of Marine Shrimp in Alabama. Journal of The World Aquaculture Society. 2007 Mar;38(1):85-91. Disponível em: https://doi.org/10.1111/j.1749-7345.2006.00076.x.

17. Chumnanka N, Boyd CE, Viriyatum R, Tunkijjanukij S. Bottom soil characteristics, survival and production of shrimp in low-salinity, inland ponds in Alabama and Florida (USA). Journal of Soils and Sediments. 2014 Dec;15(3):671-682. Disponível em: https://link.springer.com/article/10.1007/s11368014-1039-5.

18. Nehru E, Chandrasekhara Rao A, Pamanna D, Ranjith P, Lokesh B. Effect of Aqueous Minerals Supplementation on Growth and Survival of Litopenaeus vannamei in Low Salinity Water. International Journal of Current Microbiology and Applied Sciences. 2018 Jan;7(1):1706-1713. Disponível em: https:// pdfs.semanticscholar.org/b930/0b2d229fea239ac2ad07e24951454da0793a.pdf.

19. Davis DA, Boyd CE, Rouse DB, Saoud IP. Effects of Potassium, Magnesium and Age on Growth and Survival of Litopenaeus vannamei Post-Larvae Reared in Inland Low Salinity Well Waters in West Alabama. Journal of The World Aquaculture Society. 2005 Apr;36(3):416-419. Disponível em: https://doi. org/10.1111/j.1749-7345.2005.tb00346.x.

20. Costa DMA, Holanda JS, Figueiredo Filho OA. Caracterização de solos quanto a afetação por sais 
Ionic balance of water and physical-chemical properties of soil from marine shrimp farms...

Moreira F.H.G. et al.

na Bacia do Rio Cabugí - Afonso Bezerra-RN. Holos. 2004 Oct;2(1):1-13. Disponível em: https://doi. org/10.15628/holos.2004.36.

21. Cardoso-Mohedano JG, Lima-Rego J, Sanchez-Cabeza JA, Ruiz-Fernandez AC, Canales-Delgadillo J, Sanchez-Flores El, Paez-Osuna F. Sub-tropical coastal lagoon salinization associated to shrimp ponds effluents. Estuarine, Coastal and Shelf Science. 2018 Apr;203(1):72-79. Disponível em: https://doi. org/10.1016/j.ecss.2018.01.022.

22. Mcnevin AA, Boyd CE, Silapajarn O, Silapajarn K. Ionic Supplementation of Pond Waters for Inland Culture of Marine Shrimp. Journal of The World Aquaculture Society. 2004 Dec;35(4):460-467. Disponível em: https://doi.org/10.1111/j.1749-7345.2004.tb00111.x. 